\title{
Em comemoração dos 60 anos da Faculdade de Serviço Social
}

Cristina Simões Bezerra*

Prof. Marcus Vinicius David, magnifico reitor da Universidade Federal de Juiz de Fora

Prof $^{\text {a }}$ Alexandra Eiras, representante da comissão dos 60 anos da Faculdade de Serviço Social

Thayse Ribeiro de Melo, representante do Conselho Regional de Serviço Social Ana Clara Cardoso, representante do Diretório Acadêmico Padre Jaime Snoeck

Prezados professores, técnicos e estudantes da Faculdade de Serviço Social, companheiros na construção cotidiana de nossos esforços e de nossas vitórias.

Queridos assistentes sociais, ex-alunos, ex-professores, que a essa casa retornam neste momento de celebração de nossa trajetória.

Demais presentes.

Boa noite. É com grande alegria que hoje iniciamos as comemorações dos 60 anos da Faculdade de Serviço Social da Universidade Federal de Juiz de Fora.

A presença de todas e todos aqui demonstra, certamente, a importância que este espaço ocupa em nossas vidas. A ele nos devemos, como profissionais, mas também como sujeitos que construiram uma longa e gloriosa história. De certa forma, somos hoje aqueles e aquelas que a faculdade de serviço social nos ensinou a ser. Defendemos princípios e valores que, naquela casinha da rua Santos Dumont ou naqueles dois corredores do setor de estudos sociais, se materializaram e se colocaram em nossos horizontes.

\footnotetext{
* Fala proferida pela diretora da Faculdade de Serviço Social/UFJF, na abertura do seminário comemorativo dos 60 anos da faculdade, ocorrido no primero semestre de 2018.
} 
Mas a história nunca é uma via de mão única. A mesma faculdade que nos formou só existe hoje como a síntese histórica de todos os sujeitos que por ela passaram. Fomos, ao longo destes 60 anos, imensos em nossas conquistas e corajosos em nossos limites. Orientamo-nos pela certeza de que vivemos, cotidianamente, uma ofensiva direta do capital sobre nossa sociabilidade, sobre nossos direitos e nossas ações, sobre nossas potencialidades e sobre nossos limites.

Temos consciência dos profundos ataques que ameaçam hoje as universidades públicas, os servidores públicos e, sobretudo, os direitos sociais e a democracia em nosso país, reduzindo as políticas sociais, muitas vezes, a meros recursos emergenciais de enfrentamento a uma "questão social" que se agrava e se acirra em nossa sociedade. Um projeto baseado na exploração do homem e da natureza e nas diversas opressões sofridas por homens e mulheres quer nos fazer acreditar que estamos destituídos dos elementos da luta e da resistência dos trabalhadores.

Pois bem, em nossa trajetória, não nos rendemos a este projeto. Desde a tradição católica de nossa faculdade, valemo-nos da defesa da liberdade e do patrimônio do humanismo. Desde 1969, já agregada à ufjf, definimo-nos pela inserção ativa na vida universitária, contribuindo na defesa e na construção de uma universidade democrática, pública e de qualidade, socialmente referenciada; participando dos debates no campo da política social em Juiz de Fora e na região; alinhando-nos às demandas sociais e aos movimentos sociais progressistas, posicionando-nos com firmeza e autonomia, nos espaços acadêmicos e extra-acadêmicos.

Chegar hoje aos 60 anos de existência não foi tarefa facil ou desmedida. Nos últimos dez anos, muitos desafios foram enfrentados coletivamente por nossa comunidade acadêmica e muito se fez no sentido de defesa da UFJF, de uma formação profissional de qualidade e de nosso projeto ético político, de uma forma geral. Ampliamos nossas vagas discentes em torno de $20 \%$, sem, no entanto, nos rendermos aos encantos de uma expansão desordenada e não planejada. Investimos esforços coletivos no sentido da consolidação de uma graduação já reconhecida em todo o país e na implementação do curso noturno, pensado na expectativa de atender a estudantes trabalhadores e a seu direito de acesso à universidade pública e de qualidade. Orienta-nos, neste sentido, a compreensão de que nossa formação profissional precisa estar comprometida com a responsabilidade de oferecer à 
sociedade assistentes sociais capazes de lutar pela efetivação dos direitos sociais e promover perspectivas de verdadeiras transformações em nossa sociedade.

Também tivemos a oportunidade e o compromisso, nestes últimos dez anos, de avançar nas dimensões da pesquisa e da pós-graduação, através do incentivo ao trabalho de nossos grupos de pesquisa e da consolidação de nossos cursos, nos níveis lato e strictu-senso. Investimos esforços no aumento de vagas nos cursos, na ampliação e na capacitação de nosso quadro docente vinculado a pós, nas oportunidades de troca de experiência e de maior visibilidade pela participação de professores e discentes em eventos externos, na internacionalização de nossas ações, no fortalecimento de nossa revista libertas como espaço de debate e de difusão de conhecimento. Nossos grupos de pesquisa têm sido fortalecidos na perspectiva de estarem atentos às questões regionais e nacionais que problematizam a inserção do assistente social em nossa sociedade e, ao mesmo tempo, têm garantido um profícuo debate em nossas produções acadêmicas, sobretudo em monografias de conclusão de curso e nas dissertações de mestrado de nossos discentes. Neste campo, surge também nosso maior desafio e nossa maior expectativa: o projeto para nosso curso de doutorado, apresentado à capes em 2017 e sobre o qual aguardamos, ansiosamente, pela resposta.

No que se refere à extensão universitária, nossos projetos se vinculam, sobretudo, ao desenvolvimento das políticas sociais no município e região, procurando potencializar o protagonismo dos trabalhadores e das trabalhadoras em sua condução. Outro campo muito caro ao nosso trabalho é a articulação com os movimentos sociais e os demais espaços de organização dos trabalhadores, procurando articular o trabalho de nossa faculdade à pauta de suas reivindicações na garantia de direitos e de enfrentamentos em nossa sociedade. Nesta articulação, temos sido profundamente desafiados, não só por conta do contexto de restrições, do qual falamos anteriormente, mas pela necessidade de debater a compreensão e o lugar da extensão universitária em nossas principais ações coletivas.

Não podemos deixar de registrar também, nos últimos dez anos, nossa constante preocupação e nosso esforço em garantir a capacitação constante de nossos quadros docente e técnico administrativo, não só diante das necessidades constantes da formação profissional que se apresentam, mas também na organização do trabalho de gestão de nossa faculdade, dimensão profundamente relevante neste momento 
contemporâneo. A renovação de nossos quadros, sobretudo nos últimos cinco anos, tem nos apresentado estes desafios e nos garantido importantes e profícuos debates.

Somos poucos, mas isso não nos faz pequenos. Um corpo docente de 22 professores efetivos, $91 \%$ doutores, desses, $36 \%$ com pós-doutorado, 04 professores substitutos, 17 técnico-administrativos e 13 trabalhadores terceirizados. Hoje a faculdade desenvolve um conjunto de atividades acadêmicas: graduação, 4 residências, 2 cursos de especialização programa de pós-graduação em serviço social; 5 grupos de pesquisa; desenvolvimento de projetos de pesquisa e de extensão; vínculo com as instituições que oferecem campo de estágio; acompanhamento e coordenação da inserção de estagiários no município/região. Coordenação e gestão do polo de enriquecimento cultural sediado na casa de cultura, no qual são desenvolvidas atividades acadêmicas de treinamento profissional e de extensão. Inserção nacional e regional na abepss (associação brasileira de ensino e pesquisa em serviço social); e nos processos de avaliação da CAPES e CNPq. Essas atividades atendem à aproximadamente, 615 discentes.

Enfim, para abrir os trabalhos desta nossa semana, gostaria de concluir com as palavras de um de nossos egressos, que tanto nos honra hoje com sua presença e suas contribuições. Nas palavras de José Paulo Netto: "o processo de maioridade científica do serviço social brasileiro, todos o reconhecem, tem a ver com a história da nossa faculdade. Muitos dos seus egressos intervieram ativamente na construção do patrimônio de conhecimentos que hoje habilita o serviço social a uma interlocução paritária com as ciências sociais e, mais que isto, a uma intervenção ponderável na formulação de políticas públicas de âmbito nacional.

Muito obrigada. Um agradecimento muito especial de toda a faculdade, à comissão que preparou esta semana. Sejam todos e todas bem vindos e aproveitem bastante esse momento de debate. 